\title{
Analysis of Four Categories of Personnel and Their Role in the Inner-Party Supervision System of Colleges and Universities
}

\author{
Wei Su \\ Heilongjiang Bayi Agricultural University, NO.5 Xinfeng Road, Daqing, China
}

Key words: Colleges and Universities; inner-party supervision; four categories of personnel

Abstract: an important measure of managing the Party in an all-round and strict way is to strengthen inner-party supervision and perfect the system and mechanism construction of inner-party supervision. At present, the construction of inner-party supervision mechanism in colleges and universities lags behind, the implementation of supervision measures is not in place, the supervision consciousness of leading cadres and the broad masses of party members is not strong, the enthusiasm of non-party groups and personnel to participate in supervision is not enough, and the way is not enough, which has caused the poor effect of inner-party supervision in colleges and universities, and the risk of corruption is high. The staff in the inner-party supervision system of colleges and universities can be divided into four categories, namely, party committee members with party committee secretaries as the core, discipline inspection staff with discipline inspection committee secretaries as the leaders, all party members and non-party teachers, who bear different responsibilities in the inner-party supervision work. Giving full play to the role of these four categories of personnel and making them perform their respective duties plays an important role in promoting the construction of inner-party supervision system and mechanism in colleges and universities and improving the effectiveness of inner-party supervision in colleges and universities.

\section{Introduction}

In the new era, comprehensive and strict administration of the Party, as an important part of the "four comprehensive" strategic layout, is the fundamental guarantee for building a well-off society in an all-round way. Strict administration of the party, the key lies in strict administration, the vital part lies in governance, strengthening inner-party supervision is the inevitable requirement of comprehensive strict administration of the party."As a fine tradition and political advantage of Marxist political parties, strengthening inner-party supervision is an inherent requirement for the CPC to strengthen its leadership, party building and development."[1] many problems existing in inner-party supervision in colleges and universities, scholars have summarized and sorted out. This paper mainly analyzes the roles and functions of the four categories of personnel in the inner-party supervision system of colleges and universities, one is to analyze the problems existing in the inner-party supervision of the four categories of personnel, the other is to give full play to the 
respective roles of the four categories of personnel and continuously improve the effect of inner-party supervision in colleges and universities.

\section{Four Categories of Personnel in the System of Inner-Party Supervision in Colleges and Universities}

The inner-party supervision system of colleges and universities can be divided into four categories: first, the members of the inner-party committees of colleges and universities with party secretaries as the core, and the Regulations on Inner-Party Supervision of the Communist Party of China clearly stipulate that the party secretaries of colleges and universities are the first responsible persons responsible for inner-party supervision. Second, discipline inspection staff led by discipline inspection committee secretaries, who are both party committee members and the first responsible persons in supervision departments of colleges and universities, bring double responsibilities and pressures. Party members should actively exercise party members' rights and perform the supervision duties of leading cadres at all levels from bottom to top. Fourth, non-Party teachers in colleges and universities, including members of democratic parties, adhere to the basic principles of long-term coexistence, mutual supervision, mutual respect and sharing of honor and disgrace. As a member of colleges and universities, teachers should supervise the work of school party committees and party organizations at all levels in performing their duties, implementing higher-level policies and administering schools according to law with a sense of responsibility.

It can be said that these four categories of personnel, as different levels and different scope of inner-party supervision in colleges and universities, each has supervisory functions and responsibilities. The exertion of these four levels of personnel supervision functions plays an important role in the effectiveness of the supervision system of the college party.

After the 18th National Congress, the CPC Central Committee made great achievements in combating corruption under high pressure, and gradually formed a mechanism system that dared not rot, could not rot, and did not want to rot. In particular, the implementation of the inspection system has played a great role in promoting inner-party supervision and strengthening the building of a clean and honest party style, and remarkable achievements have been made in combating corruption and promoting clean government. The inspection teams sent by the Party Central Committee and the provincial party committees have played an important role in strictly administering the party, and have made great achievements, and the role of inspecting the sword is very obvious. Several rounds of inspection work have found a lot of problems, and have played a great role in promoting the overall strict administration of the party to strengthen the party. As an important field of inspection, colleges and universities have also appeared many problems in the inspection work in recent years, even serious problems of violation of law and discipline, which is shocking. In June 2017, the Political Bureau of the CPC Central Committee reviewed a special report on the inspection of the situation of the party committees in 31 colleges and universities, which pointed out that there are two main problems in colleges and universities: first, the implementation of the requirements for comprehensive and strict administration of the party is not in place, and the party committees of colleges and universities are not aware of their main responsibilities. 


\section{Personnel Factors of Weakness in Inner-Party Supervision in Colleges and Universities}

\subsection{The party committee of the school, which takes the Party committee secretary as the first responsible person, is not in place to carry out the main responsibility of inner-party supervision.}

"As the brain and heart of the operation of colleges and universities, the leadership ability and supervision efficiency of college party committees determine the future and destiny of colleges and universities."[2] the party secretary of the school is the first person responsible for supervision within the party, all the work of the school is carried out under the leadership of the party, adhere to the socialist direction of running a school, and run a university to the satisfaction of the people must take the leadership of the party as the premise and guarantee. As the concrete embodiment of the Party's leadership in colleges and universities, the Party's Party spirit, consciousness and clean consciousness will inevitably have a profound and great influence on the work of colleges and universities, and are the key human factors for the school to carry out the Party's policies. The strong party secretary has strong executive power to advance the work, but it is also easy to lead to the weakening of democratic consciousness, the weak consciousness of supervision, and even the exclusion of supervision, and regard the supervision from the discipline inspection committee at the same level and the superior and subordinate as a work obstacle. The weak supervision of the members of the school party committee, especially the party secretary, is an important reason for the frequent corruption cases in colleges and universities.

\subsection{The discipline inspection staff of colleges and universities represented by the secretary of the discipline inspection committee are not professional in their duties.}

The Regulations on Inner-Party Supervision of the Communist Party of China clearly stipulate that the Party's discipline inspection committees at all levels are the specialized organs for inner-party supervision, perform the duties of supervision and accountability for discipline enforcement, and the discipline inspection committee is the specialized organ for inner-party supervision. "Specialization" should have two meanings. The first level can be understood as a full-time or dedicated responsibility, and the second level as a professional responsibility. The supervisory discipline enforcement personnel must first be familiar with the supervision content and the party discipline party rules, grasps the rich discipline enforcement accountability way or the means, is the supervision domain expert. The reality is that the discipline inspection committee secretaries and discipline inspection committee staff in colleges and universities do not require professional background and work experience related to or consistent with the work content before engaging in discipline inspection work, that is to say, the main leaders and staff of the discipline inspection committee can be directly appointed or transferred from other departments to become familiar with the corresponding policies, rules and procedures of supervision and discipline enforcement after assuming the corresponding duties of discipline inspection committee, which often requires a short work cycle members to perform their duties adequately because they are not familiar with the policies and processes of specific supervision and discipline enforcement work. Even individual staff members have misperformed their work as a result of incorrect understanding of the policy. Some staff members are unwilling, afraid and unwilling to perform their duties of supervision and discipline enforcement because of their lack of identity, sense of belonging and sense of security in the work of the discipline inspection committee. Even individual personnel form a community of interests with the supervised object, selectively ignore the corruption problem of the supervised object, and inform them after the incident. 


\subsection{The broad masses of party members have not fully fulfilled their duties of democratic supervision from the bottom up.}

"The inner-party power in colleges and universities comes from the authorization and entrustment of the masses of the Party members, and the broad masses of the Party members in colleges and universities are the true owners of the inner-party power in colleges and universities, and the inner-party power in colleges and universities should serve and belong to the broad masses of the Party members."[3] party members are the real owners of all power within the party, party committee secretary, discipline inspection committee secretary to exercise party authority in the broad masses of party members. Therefore, although the broad masses of Party members are the object of the management of Party organizations and leading cadres, they are fundamentally the Noumenon and the main body of power granted within the Party in colleges and universities, and the service objects of the Party organizations and leading cadres. As the main body of power, the broad masses of Party members must have a sense of ownership and consciously supervise the Party members and cadres, especially the members of the Party committees of colleges and universities. "Self-criticism is afraid of losing face, criticizing superiors for fear of wearing small shoes, criticizing peers for fear of injury and anger, and criticizing subordinates for fear of losing votes,"[4] the mentality of many party members to the party supervision" regardless of their own high hanging "philosophy, resulting in the broad masses of party members unwilling to carry out bottom-up democratic supervision, always think that more than less. Party members are the vanguard soldiers with communist consciousness in the working class, and the lack of party spirit makes the inner-party supervision lose the important source of supervision power.

\subsection{The non-party teachers' awareness of participation and supervision is not strong and there is a lack of effective non-Party supervision.}

Colleges and universities have four major functions, namely, talent training, scientific research, social service and cultural inheritance. The four major functions are played by teachers as the main body, teachers are the foundation of a university, and the level and quality of teachers determine the height of colleges and universities. Although the Party is leading everything, socialist colleges and universities must run schools under the leadership of the Party, but the main force is still the vast number of teachers. In the aspect of inner-party supervision in colleges and universities, the role of teachers can not be ignored. However, at present, many college teachers only pay attention to teaching and scientific research, focusing on reporting topics, writing papers, publishing monographs, evaluating titles, giving lectures, indifferent to party building, school development, and turning a blind eye to the corruption problems of colleges and universities in the fields of scientific research, teaching, logistics, enrollment and so on. The lack of supervision outside the Party connives the formation and deterioration of corruption cases in colleges and universities.

4. Give Full Play to the Supervisory Role of the Four Categories of Personnel in Colleges and Universities, and Construct an Effective Inner-Party Supervision Mechanism

\subsection{The party committees of colleges and universities must shoulder the main responsibility of building a clean and honest party style and fulfill the overall responsibility of the first person responsible for supervision within the colleges and universities.}

Colleges and universities in our country implement the principal responsibility system under the leadership of the party committee, which is the highest power organization of the school and bears the role of the leader in the development of the school. The formulation of school policies, the 
operation of teaching and scientific research, the construction of school style of study, the cultivation of talents and other work are carried out under the leadership of the party committee. While doing a good job of all kinds of professional work, the party committees of colleges and universities, especially party secretaries, must do a good job in building a clean and honest party style, do a good job in inner-party supervision, firmly establish the consciousness that failure to pay attention to inner-party supervision is a serious dereliction of duty. The greater the power, the greater the responsibility, the higher the school party committee is at the top of the pyramid of the school power. Power must be effectively restricted and regulated in order to better serve for the performance of duties, in order to achieve the best state of power for the people. Only by putting power in the cage of the system, publicizing the duties clearly, and illuminating the operation of power with the sunshine of supervision, can we give play to the leading core role of the party committee. In order to give full play to the sharp sword function of the inspection system," the inner-party inspection system is an effective way for the party to strengthen self-supervision in the new era, and it is of great significance to strengthen the party's own construction in the new era."[5] The Party committee of colleges and universities must take the inner-party supervision as the primary duty to carry out the construction of party style and clean government, and make clear the role of the first responsible person in inner-party supervision. All party committee members with party secretary as the core should change their ideas, supervision is not a stumbling block, a roadblock, a reducer, and full supervision will not affect the development of all work in the school, but in order to promote the development of all undertakings in the school and ensure that all undertakings in the school develop in the right direction under the leadership of the party, which is the concrete embodiment of strengthening the leadership of the party.

\subsection{The discipline inspection committee of colleges and universities must shoulder the supervisory responsibility for the construction of a clean and honest party style and shoulder the professional responsibility of supervising the "great housekeeper" in the inner-party of colleges and universities.}

The discipline inspection committee shoulders the supervision responsibility of the construction of a clean and honest party style and is a special organ for inner-party supervision. The supervision responsibility is the sacred duty entrusted to the discipline inspection committee by the party constitution, and plays the role of "great housekeeper" in the supervision work within the party. It is emphasized that the supervisory responsibility of the discipline inspection committee is the return of the main cause of the discipline inspection committee, the return of the principal responsibility, the important measure of managing the party in an all-round and strict manner, and has extremely far-reaching historical significance, so the supervisory responsibility is the major political responsibility that the discipline inspection committee must shoulder. Responsibility and capacity are mutually reinforcing, and the greater the responsibility, the greater the demand for capacity. As a special supervision department within the Party, the work of the discipline Inspection Commission is highly professional and requires professional personnel. Therefore, it is necessary to strengthen the professional construction of the discipline inspection committee and cultivate and improve the professional ability of the discipline inspection staff. For personnel engaged in discipline inspection departments to set a certain professional threshold, with professionals to do professional things. The discipline inspection committee should make full and reasonable use of party discipline and party rules to carry out all kinds of supervision work. Leading cadres of party members who violate discipline should follow the principle of "learning from past mistakes to avoid future ones and treating diseases and saving lives." Therefore, in order to undertake the "great housekeeper" of its inner-party supervision, the discipline inspection committee must first practice 
internal work, improve its own professional quality and professional ability, and take the road of specialization.

\subsection{All party members in colleges and universities must have a sense of "ownership" and assume the responsibility of democratic supervision within the inner-party supervision of colleges and universities.}

The Party Constitution of the Communist Party of China stipulates that party members shall enjoy the right to "expose and report to the Party responsibly the facts of any organization of the Party and any party member that violates the law and discipline, to punish party members who violate the law and discipline, and to remove or replace incompetent cadres," while fulfilling their obligation to" bravely expose and correct the shortcomings and mistakes in their deeds and work that violate the Party's principles, and resolutely combat negative corruption ". The power of party organizations and leading cadres of party members comes from the authorization of all party members. Party members are the basic units that constitute party organizations, the most direct source of the party's combat effectiveness and leadership, and the "true master" of the Communist Party of China. All Party members must make clear this sense of "ownership ", integrate the small self of the Party members with the" big self "of the Party organizations, resolutely supervise the violations of discipline and law by the Party organizations and any Party members, and give full play to their democratic supervisory duties. The rise and fall of the country are responsible, party members as the basic components of the party's body, if let the development and spread of "cancer cells" that endanger the health of the body, unwilling to supervise, dare not supervise, do not want to supervise, not only lost the basic quality of party members, become a nominal communist, will eventually harm themselves, it is impossible to keep out of the affair.

\subsection{Non-Party teachers in colleges and universities must have a sense of participation and give full play to their responsibilities of non-party supervision.}

The Communist Party of China is the leading core of the cause of socialism with Chinese characteristics and represents the fundamental interests of the overwhelming majority of the Chinese people. The key to the realization of the Chinese Dream of the great rejuvenation of the Chinese nation depends on the leadership of the Party. The development of anything is not smooth, natural, is in the twists and turns of the continuous development. The Communist Party of China must rely on the masses to maintain its advanced nature and purity, and the building of a clean and honest party style is no exception. The purpose of the Communist Party of China is to serve the people wholeheartedly, and the leading cadres of party members are public servants of the people, not the "official masters" who are above the top. Supervision from the masses of the people is the broadest, most direct and longest-lasting supervision, and the source of the Party's ability and power to constantly improve the Party's body. Teachers in colleges and universities are a group with high academic qualifications, high quality and high consciousness among the people, and the consciousness of political participation is also strong, and the pertinence and depth of supervision are also stronger. Therefore, teachers should give full play to their own supervision advantages, actively participate in the inner-party supervision work in colleges and universities, constantly improve the effect of supervision, and promote the improvement of the inner-party supervision system and mechanism in colleges and universities. 


\section{Acknowledgements}

Study on the Special Theory of the Nineteenth National Congress of the Party of Heilongjiang Bayi Agricultural University, ProjectNo.sjd18216. And, Heilongjiang Bayi Agricultural University Support Program for San Heng San Zong, Project No.RRCPY201916.

\section{References}

[1] Qichun Liu, ianhua Chen. Historical Investigation and Practical Thinking on Inner-Party Supervision in Colleges and Universities in China since the founding of New China. School Party Building and Thought Research 2018, (06): 44.

[2] Daoyun Qian, Shouchao Zhao. A Study on the Subjectivity of Party Committees in Inner-Party Supervision in Colleges and Universities. School Party Building and Ideological Education, 2019, (02):52.

[3] Jinglei Xia. Discussion on the Constraints and Supervision System of Inner-Party Power Operation in Colleges and Universities. Journal of Henan Normal University (Philosophy and Social Sciences Edition), 2016, (06):55.

[4] Guidelines on the Party's Political Life in the New Situation. Beijing: People's Publishing House, 2016 Edition: 18.

[5] Wencheng Cai. Inspection of "sharp sword" marks new height of inner-party supervision. People's Forum, 2019, (31): 42. 